\title{
Transitional Cell Bladder Cancer in a 12-Year-Old Male Patient: A Case Report
}

\section{On Iki Yaşındaki Erkek Hastada Transizyonel Hücreli Mesane Kanseri: Olgu Sunumu}

\author{
Mehmet Çağlar Çakıcı', Sercan Sarı', Nimet Öge Köklü², Levent Sağnak', Hamit Ersoy' \\ 'University of Health Sciences, Dışkapı Yıldırım Beyazıt Training and Research Hospital, Clinic of Urology, Ankara, Turkiye \\ 2University of Health Sciences, Dışkapı Yıldırım Beyazıt Training and Research Hospital, Clinic of Pathology, Ankara, Turkiye
}

\begin{abstract}
Bladder tumors are rarely seen in childhood. However, transitional cell carcinoma of the bladder may be observed in this age group. Although they are generally low grade and the relapse rates are low, close follow-up is recommended. A 12-year-old child was brought to our clinic with the complaint of painless haematuria. Ultrasound initially detected a polypoid lesion on the right wall of the bladder. Pathological analysis revealed low-grade urothelial cancer without evidence of invasion (pTa). Bladder tumors, despite rarely seen in pediatric age group, should be considered in the differential diagnosis for patients with the complaint of macroscopic haematuria.
\end{abstract}

Keywords: Bladder cancer, pediatrics, transitional cell carcinoma

Öz

Mesane tümörleri çocukluk çağında nadir görülmektedir. Bu yaş grubunda görülen değişici epitelyal hücreli mesane tümörü çoğunlukla düşük evre ve düşük nüks oranına sahip olmakla birlikte yakın takibi önerilmektedir. Bu olgu sunumunda ağrısız makroskopik hematüri şikayeti ile polikliniğe başvuran 12 yaşındaki erkek hastayı sunmayı amaçladık. Hastanın üriner sistem ultrasonografisinde mesane sağ yan duvarda polipoid bir lezyon saptandı. Patolojik incelemede düşük dereceli non-invaziv ürotelyal kanser tanısı aldı (pTa). Mesane tümörü, pediatrik yaş grubunda nadir gözlenmesine rağmen makroskopik hematüri şikayeti ile başvuran hastalarda ayırıcı tanıda düşünülmesi gerekmektedir.

Anahtar Kelimeler: Mesane kanseri, pediatrik, transizyonel hücreli karsinom

\section{Introduction}

Bladder tumours (BTs) are rarely seen in childhood. Many reasons and risk factors for $\mathrm{BT}$ in adults have been described but etiology and prognosis of BTs in children could not be totally clarified as they are rarely seen in childhood. Transitional cell carcinoma of the bladder is caused by tumors peaking in $6^{\text {th }}$ and $7^{\text {th }}$ decades of life and observed 3-4 times more frequently in males than in females. Additionally, it has been reported that white ethnicity was associated with a greater risk (39:1) (1). While BTs of epithelial origin are common in adults, mesodermoriginated BTs are more commonly observed in children. In this paper, we aimed to present a case of transitional cell carcinoma of the bladder which is rarely seen in children.

\section{Case Presentation}

A 12-year-old child was brought to our clinic with the complaint of painless macroscopic haematuria for the last 2 months. Physical examination was normal. His body mass index was 27 $\mathrm{kg} / \mathrm{m}^{2}$. No erythrocyte and leukocyte were seen in urinalysis. His family history, environmental tobacco smoke and environmental factors were unremarkable. On urinary tract ultrasonography (USG), a polypoid nodular lesion $8.3 \times 6 \mathrm{~mm}$ in dimension was detected on the right inferolateral wall of the bladder and the upper urinary system was natural. In the cystoscopy performed with general anaesthesia, bilateral ureter orifices were observed to be natural as well as a polypoid lesion stuck nearly $2 \mathrm{~cm}$ lateral to the right orifice on the right wall of the bladder.

Correspondence: Mehmet Çağlar Çakııı MD, University of Health Sciences, Dışkapı Yıldırım Beyazıt Training and Research Hospital, Clinic of Urology, Ankara, Turkiye Phone: +90 3125962244 E-mail: mcaglarcakici@hotmail.com ORCID-ID: orcid.org/0000-0002-0176-5887 Received: 26.01.2016 Accepted: 07.05.2016

Cite this article as: Cakıcı MÇ, Sarı S, Öge Köklü N, Sağnak L, Ersoy H. Transitional Cell Bladder Cancer in a 12-Year-Old Male Patient: A Case Report. J Urol Surg 2017;4:137-139.

๑Copyright 2017 by the Association of Urological Surgery / Journal of Urological Surgery published by Galenos Publishing House. 
Monopolar transurethral resection (TUR) was performed using pediatric resectoscope to the lesion simultaneously (Figure 1) and no other lesion was seen in the bladder.

Postoperative bladder irrigation was applied until the $1^{\text {st }}$ postoperative day. The urethral catheter was removed on the $3^{\text {rd }}$ postoperative day and the patient was discharged. His pathologic assessment revealed low-level non-invasive papillary urothelial carcinoma (TaG1) (Figure 2, 3).

The patient was subjected to follow-up and cystoscopy 3 months later. Written informed consent was obtained from the parents of the patient.

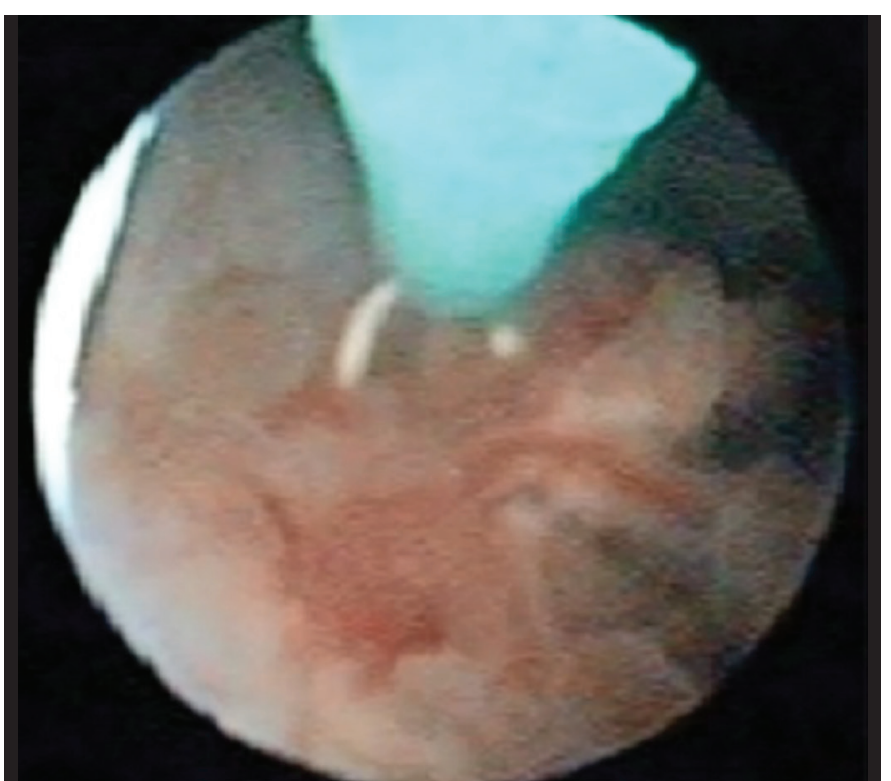

Figure 1. Transurethral resection of the papillary tumor on the right side wall of the urinary bladder

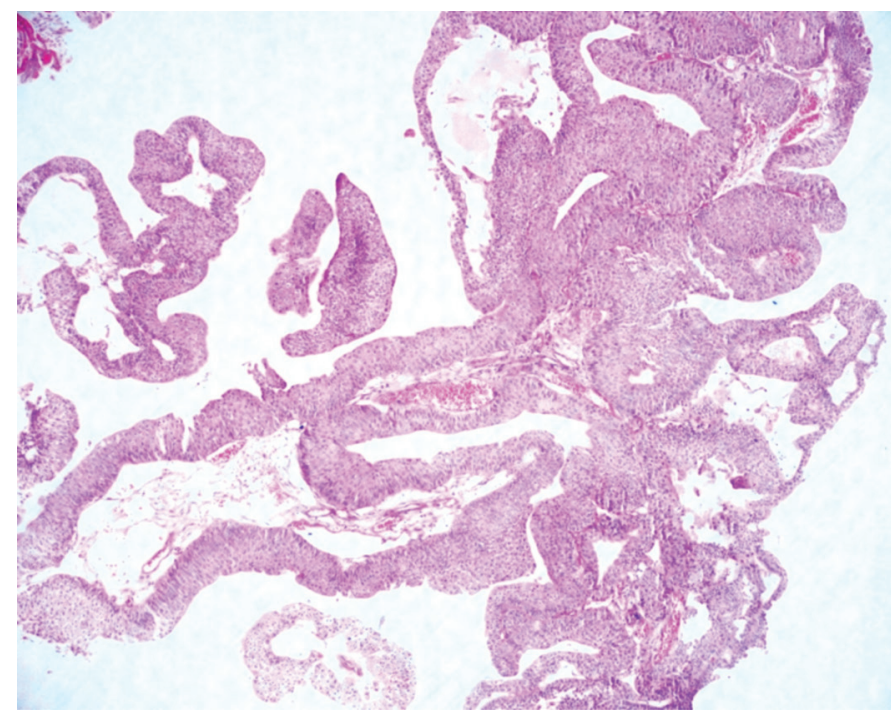

Figure 2. Low power microscopic magnification (hematoxylin and eosin, $\mathrm{x} 40$ ) of the lesion: Frondlike papillary projections that include thickened multilayered urothelium and fragments of apparently normal bladder mucosa was observed. There was not any lamina propria invasion in papillary neoplasm areas

\section{Discussion}

BT is the $11^{\text {th }}$ most common cancer worldwide. Most of the diagnosed BTs were reported to be non-muscle invasive bladder cancer.

BTs are rarely seen in childhood. In childhood, bladder cancer was first reported in 1924 (2). Recently, Lerena et al. (2) reported 125 cases of urothelial tumors diagnosed in patients younger than 20 years of age.

Although childhood BTs are generally mesoderm-originated, tumors of epithelial origin are seen far less. Many factors, such as social and genetic factors, occupational exposures, dietary habits, radiation exposure, aromatic amines, exposure to cyclophosphamide, and smoking habit play significant roles in adults. Bladder stones, Schistosoma haematobium, chronic irritation and infection are also among the factors increasing the risk of cancer. However, chronic irritation and infections were blamed in the aetiology, although the effect of these risk factors in childhood could not be totally clarified (3). Moreover, it was detected that some genetic factors are influential in terms of aetiology. In a study conducted by Keetch et al. (4), high Ki67 expression and low cycline D1 expression were found to be correlated with higher relapse rates. Although reduced p27 Kip1 expression increases the risk of recurrence in elderly individuals, it was not correlated with the increase of relapse risk in youngers. These data make us think that development and progression of BTs are shaped as a result of different molecular pathways and genetic factors (4).

The patients generally seek medical advice with the complaint of painless macroscopic haematuria. Our patient also sought

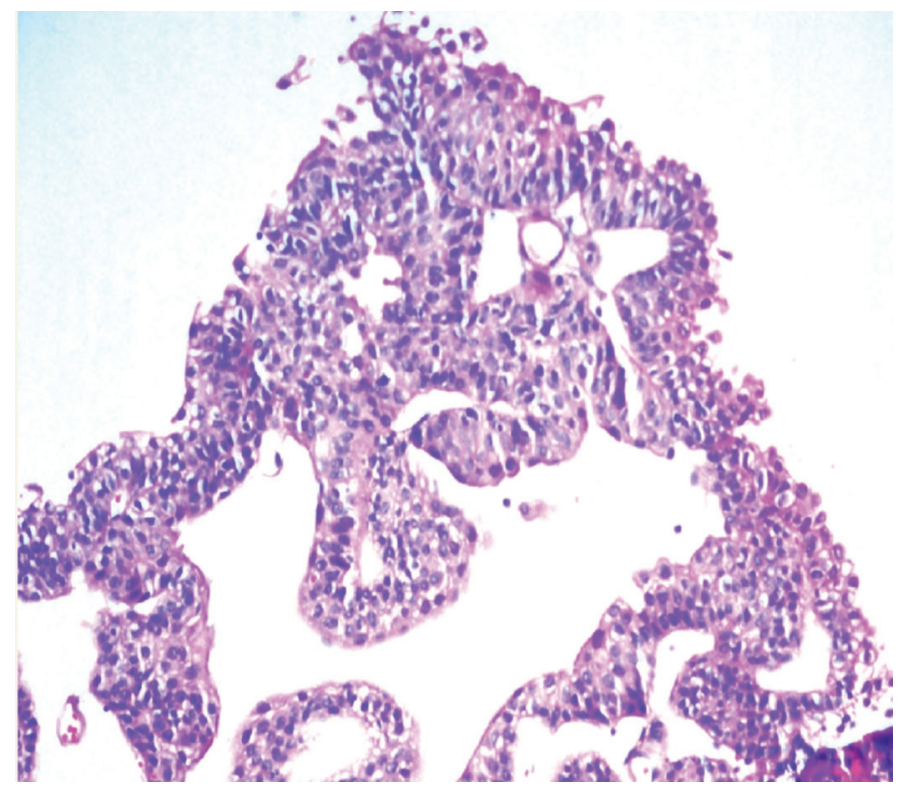

Figure 3. High power microscopic magnification (hematoxylin and eosin, $\mathrm{x} 200$ ) of the lesion: Loss of polarity, several suprabasal mitotic figure and cytologic atypia findings such as nuclear enlargement, hyperchromasia, mild differences in shape and prominent nucleoli were determined 
medical advice with this complaint. Williamson et al. (5) reported that the diagnosis of BTs might be delayed in children because of reluctance to undergo evaluation.

USG is a significant method in diagnosis. The patients are generally seen in the low stage. In 21-patient research of Fine et al. (6), low- and high-grade tumors were seen in 18 and 3 patients respectively. Urothelial papilloma was observed in 2 patients and a total of 12 patients were younger than 15 years, of whom 7 were younger than 10 (6). In childhood, transitional cell carcinoma of the bladder usually has a lower grade and stage than in older patients. Our patient also was a low-grade patient.

Transurethral resection of bladder tumour conducted under general anaesthesia is the standard procedure for treatment. There is consensus on postoperative intravesical treatment for pediatric patients $(2,6)$. Many authors use management guidelines that have been published for adults. Both mitomycin $\mathrm{C}$ and Bacillus Calmette-Guerin have been used in children, however, efficacy of intravesical treatments has not been defined due to the rarity of transitional cell carcinoma of the bladder in children (7). Postoperative intravesical treatment was not applied to our patient also.

Patient follow-up is important. There is no standardized followup procedure for children. USG and urinary cytology are the methods to be used, but the non-invasive nature is their advantage. Diagnostic cystourethroscopy is an efficient method. However, it requires general anaesthesia and has a risk of urethral damage in pediatric patients. Bujons et al. (3) recommended a follow-up of 2 years by cystourethroscopy twice a year, annual USG and urinary cytology. Although transitional cell carcinoma of the bladder seen in this age group has low-grade and relapse rates, close follow-up and cystoscopy at 3 months are recommended. If the result is negative, subsequent cystoscopy is advised 9 months later, and then, yearly for 5 years according to the European Association of Urology (EAU) guidelines. We have planned cystoscopy and ultrasound according to EAU Guidelines on Bladder Cancer every 3 months for the first year and then yearly for 5 years.
As a conclusion, $\mathrm{BT}$, despite rarely seen in pediatric age group, should be considered in the differential diagnosis for patients with the complaint of macroscopic haematuria.

\section{Ethics}

Informed Consent: Written informed consent was obtained from the parents of the patient.

Peer-review: Externally peer-reviewed.

\section{Authorship Contributions}

Surgical and Medical Practices: M.Ç.Ç., L.S., Concept: M.Ç.Ç., S.S., H.E., Design: M.Ç.Ç., S.S., H.E., Data Collection or Processing: M.Ç.Ç., S.S., N.Ö.K., Analysis or Interpretation: L.S., H.E., Literature Search: M.Ç.Ç., S.S., N.Ö.K., Writing: M.Ç.Ç., L.S., N.Ö.K.

Conflict of Interest: No conflict of interest was declared by the authors.

Financial Disclosure: The authors declared that this study received no financial support.

\section{References}

1. Madgar I, Goldwasser B, Nativ O, Hanani Y, Jonas P. Long-term follow up of patients less than 30 years old with transitional cell carcinoma of bladder. J Urol 1988;139:933-934.

2. Lerena J, Krauel L, García-Aparicio L, Vallasciani S, Suñol M, Rodó J. Transitional cell carcinoma of the bladder in children and adolescents: sixcase series and review of the literature. J Pediatr Urol 2010;6:481-485.

3. Bujons A, Caffaratti J, Garat JM, Villavicencio H. Long-term follow-up of transitional cell carcinoma of the bladder in childhood. J Pediatr Urol 2014;10:167-170.

4. Keetch DW, Manley CB, Catalona WJ. Transitional cell carcinoma of bladder in children and adolescents. Urology 1993;42:447-449.

5. Williamson SR, Lopez-Beltran A, MacLennan GT, Montironi R, Cheng L. Unique clinicopathologic and molecular characteristics of urinary bladder tumors in children and young adults. Urol Oncol 2013;31:414-426.

6. Fine SW, Humprey PA, Dehner LP, Amin MB, Epstein Jl, Urothelial neoplasms in patients 20 years or younger: a clinicopathological analysis using the world health organization 2004 bladder consensus classification. J Urol 2005;174:1976-1980.

7. Chu S, Singer J. Transitional Cell Carcinoma in the Pediatric Patient: A Review of the Literature. Urology 2016;91:175-179. 